\title{
SMS MESSAGES IN A DAILY FINNISH NEWSPAPER THE CONTEXT OF PROVERB PERFORMANCES
}

\section{LIISA GRANBOM-HERRÄNEN}

The article focuses on Finnish proverbs as a part of contemporary colloquial written language in everyday use and context. The article offers a view on what is happening with proverbs in the vernacular in Finnish everyday life. Most traditional Finnish proverbs originate from an agrarian context and still use agrarian language, even if nowadays they live in a new context with a new meaning. As empirical material this article uses a special case that demonstrates the use of proverbs in one Finnish newspaper: proverbs in SMS messages published as a letter to the editor in a newspaper. Keywords: proverb, newspaper, SMS message, contemporary life, everyday life, vernacular
Avtorica se osredinja na finske pregovore kot del sodobnega pogovornega pisnega jezika v vsakdanji rabi in kontekstu. Članek ponuja pogled na to, kaj se dogaja spregovori v domačem jeziku vinskem vsakdanjiku. Večina tradicionalnih finskih pregovorov izvira iz agrarnega konteksta in še vedno uporablja ta jezik, čeprav gre danes za nove kontekste $z$ novimi pomeni. Empirično gradivo za razpravo so pregovori vfinskem časopisu, natančneje, pregovori v SMS sporočilih, objavljenih kot pisma uredniku časopisa.

Ključne besede: pregovor, časopis, SMS sporočila, sodobno življenje, vsakdanje življenje, domače

\section{NEWSPAPER AND PROVERBS}

Studying proverbs or any kind of cultural unit means participating in an ongoing discourse in the culture in which they are used. Finnish proverbs often use old-fashioned and agrarian language, but this study has been conducted to reveal some features of proverbs used today. The study covers three dimensions of time: past, present and future. The past always runs through the present, which paves the way for the future. The present is a unique creation of the remnants of the past. What the proverbs reflect via these remnants, in most cases, has been identified from history; the findings are most often called traditional proverbs. The challenge in collecting and compiling contemporary proverbs has been and is how to find them. In any case, these kinds of collections will be sources for future paremiologic research, and on this account it is worth trying to identify various contemporary proverbs.

When my research topic about proverbs is discussed in Finland, it often encourages the question: "Proverbs! Why? Nobody uses them anymore!" Nevertheless, as it has already been proved, Finnish newspaper readers encounter proverbs on a daily basis (Granbom-Herranen 2013b, 2014b; Granbom-Herranen et al. 2015). In this way I came to deal with contemporary use of proverbs. The question I had asked myself was, "What are the most vernacular newspaper texts, that is, those that reflect vernacular language and everyday speech?" So I used an opinion column composed of SMS messages. ${ }^{1}$ The topic of this article focuses on proverbs in

1 An SMS message is a unit normally including, at most, 160 characters. Some of the SMS messages sent as letters to the editor are composed of two or even three messages. 
everyday context. They are included in SMS messages published as letters to the editor in the daily newspaper Salon Seudun Sanomat ${ }^{2}$ [Salo District Newspaper]. In this newspaper, everyday readers encounter proverbs and references to them included in published SMS messages.

The topic of proverbs and newspapers has also been studied before the aforementioned newspaper projects. The use and occurrence of proverbs in media texts have been previously analysed from various aspects (see e.g. Lüthi 1970; Mieder 1971, 2008; Piltz 1989; Chlosta et al. 1993; Carson Williams 2009). This article is continuing the so-called newspaper project, which has been a part of a co-operative study conducted in Estonia, Finland and Slovenia from 2012 to 2014 . $^{3}$ The project dealt with newspapers from a paremiologic point of view. In order to know if proverbs could be found in contemporary use, the newspapers were followed up within a one-week period in May 2012. Since the result was positive, as newspaper texts included proverbs, the next period to collect material took place during one month in May 2013. Before the pre-study focusing on newspapers in 2012, analyses from the paremiologic point of view for this three-country project mainly comprised Estonian media texts (Järv 1999; Krikmann 2005). They paved the way for pre-studies (Babič 2013; Granbom-Herranen 2013b; Lauhakangas 2013; Voolaid 2013); the material from 2012 consisted of newspapers from a one-week period. Since the studies conducted in 2012 considered various newspapers from different countries, regions and cultures, comparisons were not made. On the whole, the results gave some hints about the contemporary use of proverbs in newspapers and raised new questions for further research for each of these three countries. This article continues with these findings, combining the materials of 2012 and 2013 and concentrating on proverbs used in SMS messages in the letters to the editor column, in Finnish called Tekstarit (the vernacular form of Tekstiviestit, or SMS messages in English).

\section{THE FINNISH PROVERB IS A PROVERB USED BY THE GENERAL PUBLIC IN VERNACULAR FINNISH}

As understood in this article, a Finnish proverb is a short, independent statement in Finnish $^{4}$ that can also be understood as a generalizing expression and which is or has

2 Later also abbreviated SSS.

3 More in Babič 2013; Granbom-Herranen 2013b, 2015; Lauhakangas 2013; Voolaid 2013; GranbomHerranen \& Babič \& Voolaid 2015 as well as in Piret Voolaid's article in this volume.

4 Finnish proverbs have not been and are not used only in the Finnish language. Finnish proverbs also exist in Swedish (today Finland Swedish), Sámi (today Northern Sámi, Skólt Sámi and Inar Sámi) and Romany. In contemporary English and mixed English, proverbs exist that were originally Finnish proverbs (f. ex. "Elämä on laiffii" [Life is life], more about this proverb in Granbom-Herranen 2013b). In the future, there will surely be increasingly more mixed-language Finnish proverbs partly originating from various languages of the second- or third-generation members of the Finnish population who have an international background (in 2015 in Finland, more than 135 languages were spoken). 
been a familiar utterance within the framework of a particular time and place. The most commonly exposed characteristic of a proverb is that it is a short, independent statement in a relatively stable form, which is or has been familiar within a framework in time and place; therefore, proverbs are a shared tradition. In this article, the expression traditional proverb means an utterance that in Finland is commonly accepted to be an old proverb. ${ }^{5}$ The concept contemporary proverb includes proverbs used today, in other words, traditional proverbs, modern proverbs ${ }^{6}$ and Bible quotations as well as references to them (which are not proverbs proper). Otherwise, the concept traditional is to be understood as typical and usual either in the past or present.

The challenge of defining a proverb is not specific to either traditional or modern units of this kind. As Wolfgang Mieder says, this problem is not new; the need to define it is as old as interest in this genre. However, these days studies in folkloristic paremiology do not search for a common, universal and multipurpose definition of the proverb. This period has passed, and each researcher makes their own definitions by using those already in existence (Mieder 1993: 18). The concept proverb has never been defined in a perfect way; this task has been seen as too difficult, as there are no particular features that could indicate that a sentence is a proverb (Dundes 1981: 44). Mieder suggests that the best solution might be to agree with Archer Taylor (1981: 6), who has stated that "an incommunicable quality tells us this sentence is proverbial and that one is not". Anyway, as Finnish folkloristic scholar Lauri Honko (1989: 14) says: "It is not always necessary, or even possible, in the dynamic research tradition to define the key concepts exhaustively, for there must always be room for new connections".

In this study, one of the starting points for identifying an utterance as a proverb leans on Paul Grice's cooperative principle including categories of quantity, quality, relation and manner (Grice 1975: 45-46), even if Grice's categories are not exclusionary ones. All these categories can be violated either consciously or subconsciously. The use of a proverb violates one or more of the abovementioned categories. The way one recognizes the proverb in speech or a text is problematic in a similar manner to the way one recognizes a metaphor. Their meaning is based on differences from the ongoing discourse and they conflict with a proper speech act. ${ }^{7}$

5 Most of the traditional Finnish proverb types are included in these three published collections: Nirvi \& Hakulinen 1953 [1948], Kuusi 1993 [1953] and Laukkanen \& Hakamies 1997 [1978]. The concept proverb in Finland has primarily been advanced to coincide with the types and structures presented in the aforementioned publications.

6 Modern proverbs have many names in paremiologic etic language (Granbom-Herranen 2011: 286). Sometimes the concept modern proverb is bound with some special timeline or year (cf. Mieder 2014: 17). In this article the concept modern proverb means the contemporary use of a proverb, which is neither a traditional proverb nor a Bible quotation.

7 For more about proverbs and the cooperative principle, see Granbom-Herranen 2010b: 49, $2014 \mathrm{a}$. 
What is meant by the term proverb (sananlasku) is quite clear to Finnish proverb users, even if it is not as clear as Mieder and Shirley Arora note in their proverb materials for English speakers (Arora 1994: 4; Mieder 1993: 36). It is obvious that users of proverbs cannot always identify proverbs or determine a difference between proverbs and other proverbial expressions (see also Čermák 2005; Järv 1999). Another question is whether it actually matters if we accept the two parallel ways to see proverbs: on the one hand, the emic language that is known within a group and, on the other hand, the researchers' etic language (Headland 1990). I tender to count with the emic definition as I have accepted the view of proverb users. Sometimes the concepts proverb, saying, Bible quotation, etc. are used as synonyms, but all these indicate the proverbiality of a given expression.

Proverbs in spoken language are in many ways the same as proverbs in the colloquial written form in media language, everyday political rhetoric, the mass media or on the Internet. This might be crystallized in the following example taken from the wider material. The examples deal with one proverb which occurs both as a traditional proverb and a modern one. The first example tells about a time about 80 years ago, and the two others are from 21st-century SMS material. The ground form of the proverbs says: Niin metsä vastaa kuin sinne huutaa. [The forest answers as somebody shouts to it]. The meaning is that everybody gives and receives at the same level.

\section{LIFE STORY}

When talking about the neighbours, my parents pointed out that all people, both richer than us and more in need than us, whether duller by nature or more communicative, were in some way all good people. They wanted to find something valuable in the blameworthy person. Just as a throwaway remark and by using some proper proverb, they often ended with the saying:

- Tuumoo kahesti, ennen kun tuomihet [Think twice before you judge], or - Huonokii mehtä vastaa niin ku ite huuvat [Even a bad forest answers as you shout to it] (PE85, man, born 1914)

SMS

Anyway, I have gotten along with the townspeople very well. Kummottos mettä buutta, simmotsevasta. [The way you shout to a forest, that is the way it answers] - a local resident (SSS, sent 19. 8. 2006)

It was nice when we got a new school. There every teacher has their own laptop and many other fine things. Art was bought with 9,000 euros. Now we have to save money. - sitä saa mitä tilaa [you get what you order] (SSS, sent 18. 8. 2006) 


\section{A PROVERB AS AND IN A SHORT PERFORMANCE}

Research on the use of proverbs as and in a performance is based on folklorist Charles Briggs's (1988) ideas of proverb performances combined with the idea of Alain Badiou's event (Badiou 2009). The significance of an utterance has some starting points: first, language is not understood only as an instrument of communication but as linked to a thought (Vygotski 1967); second, I used Gottlob Frege's (2000) principle of context; and third, in order to be understood and interpreted, an utterance should follow Grice's (1975) cooperative principle. ${ }^{8}$ The best known folkloristic scholars dealing with proverbs and performance theories are Briggs and Richard Bauman (Briggs 1988; Bauman \& Briggs 1990; Bauman 1992).

The performance concept includes both verbal expressions and the behaviour by which the message is broadcast (Bauman 1992). Use of a proverb is a small performance which has a target bound with the situation and used words (Briggs 1988). A performance is always an interaction between the sender of some message (the speaker or writer using proverbs) and the audience (a real or assumed one). A proverb as or in a performance might be treated as what Badiou (2009) calls an event (or the proverb paves the way for an event); it might change the significance of the entire occasion. The proverb is often aimed at hitting an authentic and on-off note by terminating the speech or written text. The successful proverb performance sums up the kernel of the performance. It can function as a full stop. In the analysed SMS messages, 80 percent of proverbs or references to them were used in the signature. At the end of the message, they were used to sum up what was implemented or to make a full stop.

When making a pause in the discourse, the use of the proverb as a violating element introduces some new aspects. As an event or a short performance, the proverb is a fixed part of the entire situation: something is happening and proverbs might be identified with some tying phrase or markers (Čermák 2005). The proverb might be presented within some framework, like a word or a gesture, when some utterance is pointed out by the speaker - the author uses a proverb or saying to assure readers or listeners. In any case, the proverb as well as the interpretation is aimed at being associated with the situation. Some presumptions always exist behind the proverb, like an expected ground meaning 9 (or SPI) of the ground form as well as hypothetical situation for the proper use of a proverb. The

8 For more about how the significance of proverb is understood in this article, see Granbom-Herranen 2008; 2010b; 2013a.

9 Ground meaning is a culture-bound standard proverbial interpretation (SPI) that is understood as the universal, so-called correct interpretation (Norrick 1985: 109-117). The SPI presupposes universality and is often seen as a correct interpretation when cultural prejudices are involved. According to Hilary Putnam (1975), universality of features among languages means universal structures, not universal meanings. Furthermore, similarity in intention, at a micro level, does not mean similarity in extension, i.e. at a macro level. 
association is not always what could be expected by knowing the ground meaning, as the significance and interpretation is actually in the context. Its use is meaningful in the particular context. Proverbs gain relevance in time and place, and the context in which they are to be understood as quite a wide concept. A proverb is used to affect something in some way; actually, in many cases the proverb user's role is often that of the wise man or that of the court jester.

As for the features of a proverb performance, Briggs (1985: 798-802) mentions that a proverb is a fixed part of some totality in which the owner of the proverb legitimizes what has been said. Often some verb is used to frame the proverb. A proverb is used as a helping hand, most often in the following constructions: "as the proverb says", "even a saying tells us", "you know the saying", "unlike the proverb says", "as everybody knows", "my grandmother used to say". František Čermák (2005) postulates that speakers may feel that it is necessary to introduce whatever they are going to say next by a word or combination of words. Čermák calls the units used in this function introducers of proverbs. When using a proverb, the speaker (or writer) leans on some authority of the past,${ }^{10}$ linking a third party to the situation. This has been verified especially within the pedagogical discourse (Briggs 1988; Granbom-Herranen 2008, 2013c). Every time the proverb is heard, it is related to the owner of the proverb, which is actually a combination of the person and the situation in which it was heard for the first time. Life stories also give descriptions of the emotions, feelings, and sensations present in the situation the proverb had been heard in. All this is linked with a proverb. Proverbs, as a part of folklore tradition, have been assumed to be the domain of the elderly and are supposed to be transferred from generation to generation. For example, the feature "handed down from generation to generation" (Mieder 2004) of proverbs is something that needs to be re-evaluated. However, from whom or where the proverb has been heard is not normally seen in SMS messages. (Granbom-Herranen 2010b: 63.)

A proverb is an utterance which functions as an event in a performance or as a short performance: it puts ideas together by referring to something that is supposed to be well known or a fact when the messages (e.g. a story) is repeated. It is easily remembered because of its form (shortness, rhythm). Today, besides SMS messages in newspapers, sermons and political speeches are examples of small performances where proverbs in oral and written form are comparable with each other. In everyday use, the speaker does not plan how to use proverb (when, where, in what form and to whom). Evidently, this happens in the same way as in colloquial written language. When making a pause in the discourse, the use of a proverb as a violating element introduces some new aspects (Granbom-Herranen 2010b: 48-50). In any case, the use of a proverb or a proverb itself adds value to the speech event. Following Briggs's definition of the proverb performance, all the following features of proverbs can be found both in oral use and colloquial texts: the proverb is a fixed part

10 The past does not always mean ancient times or when "elders of bygone days" lived, as Briggs (1988: 100) has said. 
of the event; there is an owner of the proverb; there is a verb that frames it; it aims at being associated with the situation; there is an expected ground meaning ${ }^{11}$ behind the proverb; the use of the proverb is meaningful in a particular context; and it is used by the speaker in order to be assertive (Briggs 1985: 798-802). These presentational features do not disappear when the proverbs are moved to new setting, from speech to colloquial written language. Some common features behind the proverb performance in the verbal form and colloquial written language are quite obvious. The performer and the audience must share some common knowledge about the past in order to be able to relate the message to the activity. ${ }^{12}$ Every proverb performance is interactive, and the communicative occasion is produced by the performer (speaker or writer) and the audience (listener or reader) together, even if feedback is not given immediately.

\section{CONTENT ANALYSES USED IN NEWSPAPER MATERIAL}

Salon Seudun Sanomat is a regional newspaper. It is targeted at average people for everyday reading and it includes regional, national and international news. The newspaper is published daily except following some public holidays in Finland, such as 1 May. Established in 1919, it has always been published in Finnish. In 2009, the daily circulation of the newspaper was about 20,000 with about 50,000 readers (Granbom-Herranen 2013b). Most of the readers live in Salo and the surrounding area; Salo is a coastal town of about 54,500 inhabitants in the prosperous south-west region of Finland. It is worth noting that up to the 2010s, Salo was connected closely with Nokia and mobile phones, as much of Nokia's mobile phone industry as well as the research and development laboratory were situated in Salo. This means that directly or via subcontractors, as well as due to the need for all kinds of services, approximately half of the inhabitants made a living from Nokia's welfare. Meanwhile, the countryside in the Salo region represents the most agrarian area in Finland.

The newspaper began to publish the column for opinions sent as SMS messages in 2006 and was among the first newspapers in Finland to do so. This might have had to do with the fact that from the beginning, Nokia's mobile phones have been constructed for SMS message use. The column was first published five days in a week, but quite soon this column became a fixed and daily part of Salon Seudun Sanomat. The SMS messages column has always been located on page 2, always appearing in the same corner of this page (see Figure 1). The column Tekstarit contains 25-30 SMS messages per day, which is approximately a third of the messages the newspaper receives. Weekly, the published

11 As above in footnote 8 .

12 However, there are always listeners and readers who are incapable of understanding and/or interpreting proverbs and even fewer the references to proverbs (Granbom-Herranen 2008: 184; Ferretti et al. 2007). 
SMS messages include a minimum of five proverbs or references to a proverb. ${ }^{13}$ As Salon Seudun Sanomat is a regional newspaper, it is relevant to assume that the SMS messages are produced by people living or working in the Salo region. Proverbs are transmitted in the form of cell phone SMS messages and act as letters to the editor, published in a column designated for opinions. Regarding the ethical issues in this study, the proverbs published in the newspaper are already public and the examples presented in the newspaper are given with the pseudonyms used by the authors of the messages.

By the term newspaper, I mean what a person physically gets as the paper version of the newspaper subscription. I have used the paper versions of newspapers. The reason for this choice is that the Internet version does not have free access, whereas the paper version is available in public libraries, so it is possible to read it for free across Finland. The paper version is written and published for average people. The first phase of the material collection was done over the course of one week (from Monday, 7 May to Sunday, 13 May in 2012) and the second phase over one month (from 1 May to 31 May 2013). The collected material includes all published SMS messages sent to Salon Seudun Sanomat.

In total, there were more than 50 proverbs, of which about 80 percent were used as signatures or a part of the signature of the opinion, as mentioned before. Contrary to what was expected, only three proverbs occurred with a marker:

Sanotaan, että kissa kiitoksella elää. Mutta saisi edes kiitoksen. - Auttaja (SSS 11.5.2013)

It is said that a cat lives on thanks. - But it would be nice to get even a thanks - Helper

Utelias. Taitaa olla asioiden käsittely vielä kesken. Odottele rauhassa, kyllä se siitä.

- Sanoi Manukin aikoinaan (SSS 23.5.2013)

Curious. The discussion seems to be unfinished. Just wait in peace, it works out. - Said also Manu back in the day

Sanotaan, että hanki elämä. Mistä sen voi ostaa. - Paljonko maksaa (SSS 28.5.2013)

It is said, "Get a life". But where is it possible to buy one? - How much does it cost

Out of the 53 contemporary proverbs, 22 were related to traditional proverbs ${ }^{14}$ and 29 to modern ones. ${ }^{15}$ Bible quotations were mentioned two times.

13 In newspaper opinion columns made up of SMS messages in the year 2012 (one week) and 2013 (one month), there were 1-4 proverbs (or references to them) published daily. In 2013, the one-month period included five days (4, 5, 16, 18 and 30 of May) without any proverbs in SMS messages.

14 In total, 9 proverbs and 13 references to proverbs.

15 In total, 24 proverbs and 5 references to proverbs. 


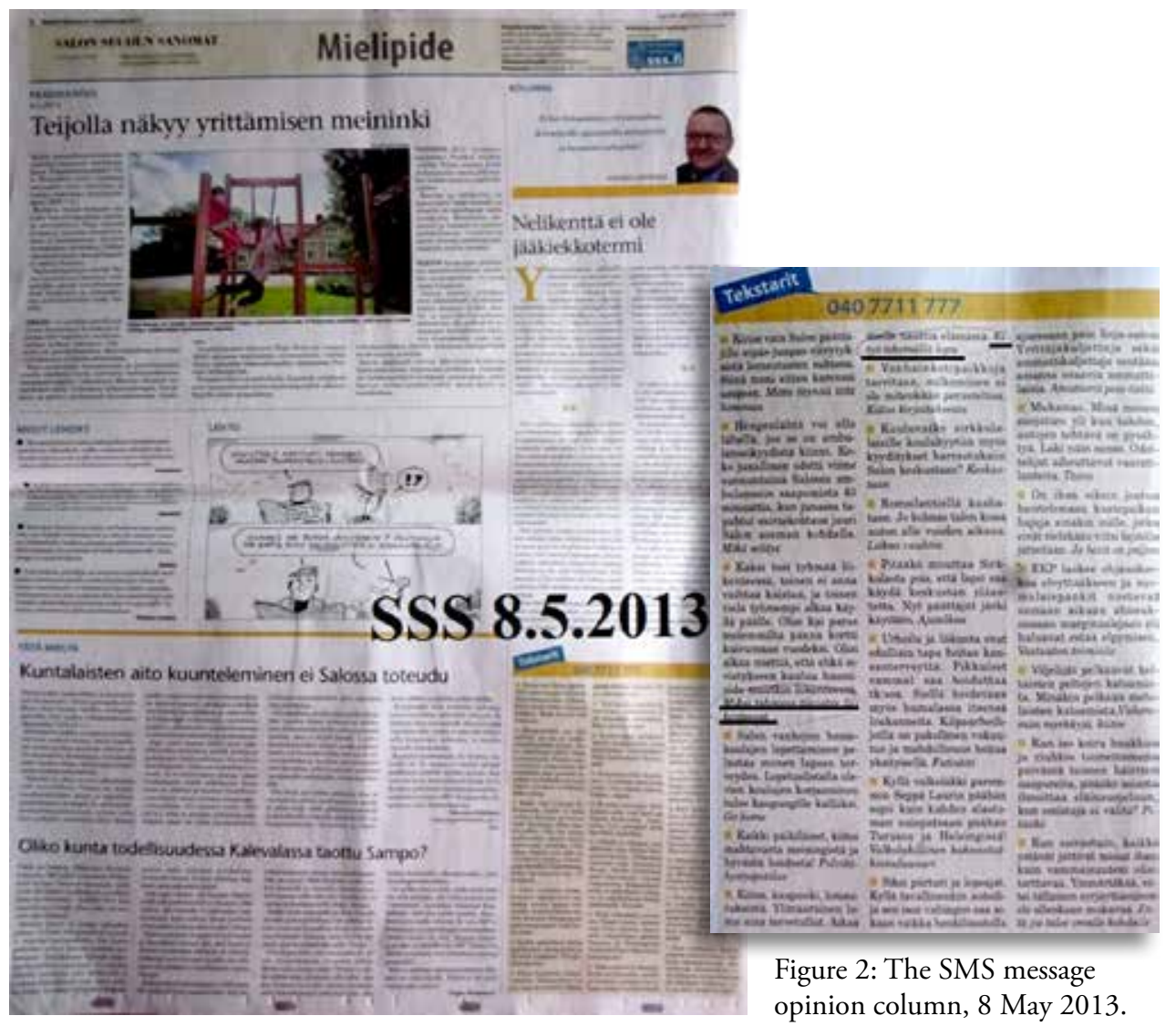

Figure 1: Page 2 of SSS, of 8 May 2013.

For example, in the newspaper of 8 May 2013, there were two SMS messages with a proverb, as seen in Figure 2. The first one says:

Kaksi tosi tyhmää liikenteessä, toinen ei anna vaihtaa kaistaa, ja toinen vielä tyhmempi alkaa käydä päälle. Olisi kai paras molemmilta panna kortti kuivumaan vuodeksi. Olisi aika miettiä, että ehkä sivistykseen kuuluu huomioida muutkin liikenteessä. Miksi tyhmyys tiivistyy liikenteessä

Two really stupid persons are stuck in traffic. The first one gives no opportunity to change to another lane and the other one, who is even more stupid, lashes out. It would be better to take their licenses away for a year. They would have time to think that one part of education is to take other people in traffic into account. - Why stupidity grows more intense in traffic

Joukossa tyhmyys tiivistyy [Stupidity grows more intense in a crowd] is the ground form of this traditional proverb. 
The second one says:

Kiitos, kaupunki, lomautuksista. Ylimääräinen loma aina tervetullut. Aikaa itselle nauttia elämästä. - Ei tÿ̈ tekemällä lopu

Thank you, town, for the temporary dismissals. The extra holiday is always welcome. You'll have time to life. - Work will not run out by doing

Ei työ tekemällä lopu [Work will not run out by doing] is a traditional proverb (as well as a proverb proper).

I have used mixed methods, even though the emphasis is put on qualitative research. The central research method is content analysis, which is understood as a cluster of methods connected with conclusions based on theoretical analyses (Granbom-Herranen 2010a). Content analysis is commonly used with existing text material such as texts in newspapers (Grönfors 1982) and it differs from discourse analysis, which also concentrates on communication in the written form (Jussila et al. 1992). The SMS messages in the column do not form the kind of a direct dialog or communicativeness that is required by discourse analysis.

I have divided the content analysis into phases. During the first phase, in May 2012 and May 2013, I acquainted myself with the newspaper as a whole. Proverbs in newspapers have been approached from the reader's point of view, and in practice this means I read them daily the way all newspaper readers do. In the second phase, I defined the working concept of proverb for contemporary Finnish use. I focused on the units consisting of a sentence or a part of a sentence (see Granbom-Herranen 2014b). The third phase concerned identifying the proverbial utterances in the SMS messages. For identification purposes, besides my knowledge of paremiology, I used Grice's cooperative principle (Grice 1975), leaning on the fact that all proverbial expressions in some way violate one or more categories in Grice's cooperative principle and in discourse they function like Badiou's event (Badiou 2009). In this phase I identified and recorded all kinds of proverbial expressions, including phrases and idioms. The context was analysed to help to identify proverbs in the texts as the meanings of the proverbs came from their context. The categorisation gives an idea about the quantity and shows whether a proverb is common or rare. In this phase, I excluded expressions that were not to be considered as proverbs even in the framework of the loose definition of proverbs, which also comprises the references to proverbs as well as possible proverbs. The expressions were combined with the context ${ }^{16}$ and were examined via the ground form of the proverb, which might be called the proverb proper behind an utterance. Phase four involved the classification of the proverb material.

16 The context of a proverb in an SMS message consists of the idea of the SMS message, the opinion column (including previous days), news in the paper (including previous days) and activities in society; these factors are used to determine the reasons for sending the SMS-message with a proverb. 
Most of the proverbs occurred only once in these periods. Five proverbs occurred or were referred to twice. One and the same proverb was used or referred to, at most, three times. The ground forms of proverbs were as given below:

Elä ja anna muidenkin elää [Live and let other people live] (SSS 24.5.2013; SSS

25.5.2013; SSS 26.5.2013)

Tasan ei käy onnen lahjat [The gifts of luck are not equally divided] (SSS 1.5.2013;

SSS 9.5.2013; SSS 10.5.2013)

Tosi on [True it is] (SSS 7.5.2012; SSS 8.5.2013; SSS 21.5.2013)

The last one, Tosi on, is a modern expression originating from the slogan from the $1980 \mathrm{~s}^{17}$ of former very national Finnish bank, Kansallispankki. ${ }^{18}$ This expression is used here as a modern proverb, since it is seen as a meaning-carrying unit with a reference point. It gains significance from the fact that there is a strong connection between the expression and the idea that could be called "his master's voice". In other words, what is said is said with the authority given by property. What is said is supposed to be taken as truth ("True it is") and should not be questioned.

Among those referred to twice, there was one Bible quotation (the only one in this material). The second reference to the quotation from the Bible was an answer to the SMS message using the same quotation. Anna heille anteeksi, sillä he eivät tiedä, mitä he tekevät [Forgive them, for they know not what they do] is the ground form of the kernel of this Bible quotation.

The Bible quotation in its entirety says:

Mutta Jeesus sanoi: "Isä, anna heille anteeksi, sillä he eivät tiedä, mitä he tekevät" (Luuk. 23:34)

[And Jesus said, Father, forgive them, for they know not what they do. (Luke 23:34)]

The first SMS message is as follows:

Annan anteeksi niille jotka sormella osoittelevat ja perättömiä juoruja levittävät, sillä he eivät tiedä mitä tekevät. - Itsellä helpompi olla (SSS 20.5.2013)

I forgive them who point a finger and spread cock-and-bull gossip, for they know not what they do. - It is easier for me to live

17 The commercial can be seen at: https://www.youtube.com/watch? $v=m K K r z 6 b w I E g$

18 Kansallis-Osake-Pankki (KOP) was a Finnish commercial bank operating from 1889 to 1995 . In the 1980s, it was called Kansallispankki [National Bank]. It was created by the Fennoman movement as a Finnish language alternative to the largely Swedish language bank, Suomen Yhdyspankki https:// en.wikipedia.org/wiki/Suomen_Yhdyspankki (the Swedish name of the bank is Föreningsbanken i Finland). The two banks were merged in 1995 to form Merita Bank, which was later merged with Swedish Nordbanken to form the still existing Nordea. https://en.wikipedia.org/wiki/Kansallis-Osake-Pankki 
The second one is the answer to the first message:

Itsellä helpompi olo. Minä en anna perättömien juorujen puhujille anteeksi. Kyllä tietävät mitä tekevät. Tietämättömyys antaa ihmisille paljon luultavaa. - Tieto ja luulo (SSS 27.5.2013)

It is easier for me to live. I do not forgive the speakers of cock-and-bull gossip. They know what they do. Lack of awareness gives people a lot to believe. Knowledge and belief

The second SMS message includes a reference to a traditional proverb with the ground form Luulo ei ole tiedon väärti [Belief is not knowledge].

I speak of the paradox of proverbs when we are looking at the possible proverbs that are utterances which might be considered to be proverbs in the future rather than today. For example, many definitions for a proverb say that it is an old expression. Yet, it is difficult to know which contemporarily used expressions will still be around decades from now. It is a challenge to define a modern or future proverb, or to recognize potential proverbs before they actually become proverbs. The difficulty consists in the fact that when collecting these expressions, we cannot know which ones will last. It also means that there ought to exist a clear and handy understanding of proverbs, including old and traditional ones as well as contemporary, modern ones and future ones. (Granbom-Herranen et al. 2015; Granbom-Herranen 2016.) By not allowing for the inclusion of potential proverbs, the existing definition does not support research of proverbs in present-day contexts (Grzybek 1987: 40). The paradox is that old proverbs are recognizable, but modern or future ones are not. One can easily come to the conclusion that there are no modern proverbs, as no one can tell which expressions will become established in that way. Indeed, how is it possible to look for expressions that cannot be defined or determined even if they exist? How can a new or future proverb be defined or potential proverbs be recognized before they are actually proverbs? As mentioned at the beginning of article, collecting any kind of cultural unit means participating in an ongoing discourse in the culture in which they are used, as well as in a broader context. In the same way, as the past is a combination of social, economic, geographical and other cultural factors, the present is a unique creation of those remnants of the past. The challenge in collecting contemporary proverbs consists in finding them. The same challenge is met in all folkloristic studies: old traditions are known but when they appear in the middle of contemporary traditions, they are so obvious that they might be unnoticeable and the future traditions may still be unknown. 


\section{CONCLUSIONS}

The column for letters to the editor in the form of SMS messages includes contemporary proverbs, that is to say, traditional proverbs, modern proverbs, Bible quotations and references to them. Defining the concepts traditional proverb and modern proverb is challenging. The most important factor is to follow the chosen definition in one study. Even if it might be valid only within the study at issue, it provides information for further research. The easiest way is to point out references to traditional proverbs because once the ground forms of proverbs are defined, the references are quite easy to recognize. As mentioned above, it is quite a challenge to recognize potential proverbs before they actually are considered to be proverbs. The paradox is that old proverbs are recognizable, but contemporary or future ones are not. One can easily come to the conclusion that there are no new proverbs, as no one can tell which expressions will become established in that way. With regards to performance, no fundamental differences actually exist between oral use and use in colloquial written language. The presentational characteristic does not disappear when such utterances are shifted into a new environment. Traditional proverbs, references to proverbs, modern proverbs and Bible quotations are used in written vernacular Finnish.

The urban lifestyle has caused changes to the modern Finnish proverb tradition. Most Finnish proverbs still use agrarian language, although today they are often used in a new context with a new meaning. Proverbs are not always similar to their predecessors; earlier oral tradition has found a place in the colloquial written language because these days the native Finnish-speaking population of Finland can read and write Finnish. This has changed the position of proverbs in the Finnish language. When a proverb is used, the authority of the earlier proverb speaker might be expressed too. However, this statement is unclear in the urban tradition and is not pedagogically oriented. In any case, the earlier speaker does not have to come from the distant past. The earlier speaker is somebody who has used the proverb but this has nothing to do with the invoker of the proverb. ${ }^{19}$

In spite of many changes in recent decades to the Finnish society and lifestyle, proverbs still belong to everyday use and communication. In Finnish, the written colloquial language has taken its place alongside the spoken one. There are some discrepancies as well as similarities between proverbs in everyday life, proverbs in the media and proverbs in literature. Nevertheless, despite many changes in life and everyday practices, it can be said without any hesitation that Finnish proverbs also appear in contemporary Finnish language and they have their place as a part of Finnish communication. They are not relics of an ancient time. Proverbs are still used as rhetorical tools of powerful speech or vernacular writing, and this is why readers of newspapers encounter them daily. Proverbs are alive as

19 Taylor does not take into account only old and existing proverbs, but he also points out that a proverb can be either an old or a new comment; yet, the circumstances make the proverb widespread and well-known (Taylor 1981: 3-8). 
long as they are used or referred to in everyday communication which takes place within a group or between some of them. Proverbs, including traditional and modern ones as well as proverbs like Bible quotations, still have their place urban and new technology environments. This means that when we look for proverbs in speech and texts like speech, we must look at proverbs, shortened proverbs, or references and allusions to some proverbs.

On one hand, the results of these periods in Salon Seudun Sanomat, a Finnish regional newspaper, (one week in 2012 and one month in 2013) differ from previous studies. For example, there were hardly any proverbs with markers different from those found by Čermák (2005) or Risto Järv (1999). Moreover, in a co-operative study between Estonia, Finland and Slovenia (Granbom-Herranen \& Babič \& Voolaid 2015) we found some examples of this kind of target-orientated use of expressions. This might be explained by the fact that the majority of proverbs with markers gleaned from interviews and SMS messages as letters to the editor do not use the rhetoric of interview. On the other hand, the results of SMS messages from these periods correspond to many conclusions of the previous research. ${ }^{20}$ When it comes to proverbs used in SMS messages, it is obvious that traditional proverbs are acquiring new forms, proverbs (traditional and/or modern) are combined, traditional proverbs are to be found with new connections, modern proverbs are created by using traditional proverbs, and traditional proverbs are transformed, sometimes as parodies of old traditional expressions. Finnish vernacular proverbs belong to everyday use and communication, although the context for proverbs has changed over a period of one century.

The study was supported by University of Turku and the Finnish Cultural Foundation's Varsinais-Suomi Regional Fund.

\section{SOURCES}

PE85 = Perinne elämässäni - kilpakirjoitus 1985 [Tradition in my life - writing competition 1985] Suomalaisen Kirjallisuuden Seuran kansanrunousarkisto [The Folklore Archives of the Finnish Literature Society in Helsinki, Finland]

SSS $=$ Salon Seudun Sanomat, Finnish daily newspaper from 7 May to 13 May in 2012 and from 1 May to 31 May 2013 published SMS-messages and year 2006 sent SMS-messages

20 On one hand, proverbs and newspapers (Babič 2013; Granbom-Herranen 2013b, 2015; Lauhakangas 2013; Voolaid 2013; Granbom-Herranen et al. 2015); on the other hand, SMS-messages in newspapers (Granbom-Herranen 2011, 2013b, 2014a, 2014b). 


\section{REFERENCES}

Arora, Shirley L. 1994. The Perception of Proverbiality. In: Wolfgang Mieder (ed.), Wise Words: Essays on the Proverb. New York: Garland Publishing, 3-29.

Babič, Saša 2013. The Use of Proverbs in Slovene Language (The Newspaper Project). In: Rui J. B. Soares \& Outi Lauhakangas (eds.), 6th Interdisciplinary Colloquium on Proverbs. Tavira: IAP-AIP, 426-435.

Badiou, Alain 2009. Being and Event. New York: Continuum.

Bauman, Richard 1992. Folklore, Cultural Performances, and Popular Entertainments. New York, Oxford: Oxford University Press.

Bauman, Richard \& Briggs, Charles L. 1990. Poetics and Performance as Critical Perspectives on Language and Social Life. Annual Review of Anthropology 19, 59-88.

Briggs, Charles L. 1985. The Pragmatics of Proverb Performances in New Mexican Spanish. In: American Anthropologist vol. 87, 793-810.

Briggs, Charles L. 1988. Competence in Performance. Philadelphia: University of Pennsylvania Press.

Carson Williams, Fionnuala 2009. Proverbial Expressions, the Local Press and the Current "Troubles" in Northern Ireland. In: Mare Kõiva (ed.), Media and Folklore: Contemporary Folklore IV. Tartu: ELM Scholarly Press, 216-238. http://www.folklore.ee/rl/pubte/ee/cf/cf4/CF4_Williams.pdf

Chlosta, Christoph \& Grzybek, Peter \& Stankovič-Arnold, Zorica \& Steczka, Andreas 1993. Das Sprichwort in der uberregionalen Tagespresse: Eine systematische Analyse zum Vorkommen von Sprichwörtern in den Tageszeitungen ,Die Welt', ,Frankfurter Allgemeine Zeitung' und ,Suddeutsche Zeitung؛. Wirkendes Wort: Deutsche Sprache und Literatur in Forschung und Lehre 43 (3), 671-695.

Čermák, František 2005. Text Introducers of Proverbs and Other Idioms. In: Phraseologismen als Gegenstand sprach-und kulturwissenschaftlicher Forschung, 57-77.

Dundes, Alan 1981. On the Structure of the Proverb. In: Wolfgang Mieder \& Alan Dundes (eds.) The Wisdom of many. Essays on the Proverb. New York \& London: Garland Publishing, 43-64.

Ferretti, Todd R. \& Schwint, Christopher A. \& Katz, Albert N. 2007. Electrophysiological and Behavioral Measures of the Influence of Literal and Figurative Contextual Constraints on Proverb Comprehension. Brain and Language 101 (1), 38-49.

Frege, Gottlob 2000. On the scientific justification of a conceptual notation. Gottlob Frege (ed.): Conceptual notation and related articles. Oxford: Clarendon Press, 83-89.

Granbom-Herranen, Liisa 2008. Sananlaskut kasvatuspuheessa. Perinnettä, kasvatusta, indoktrinaatiota? [Proverbs in pedagogical discourse. Tradition, upbringing, indoctrination?] Jyväskylä Studies in Education, Psychology and Social Research 329. University of Jyväskylä. (includes a summary in English). [online] http://urn.fi/URN:ISBN:978-951-39-3111-7 last accessed on 18 Dec, 2015.

Granbom-Herranen, Liisa 2010a. Menetelmät monitieteellisen tutkimuksen haasteena [Multidisciplinary Research Is a Challenge for Research Methods]. Elore 17 (2): 68-78. http://www.elore.fi/arkisto/2_10/herranen_2_10.pdf, last accessed on 15 March, 2015.

Granbom-Herranen, Liisa 2010b. How Do Proverbs Get Their Meanings? The Model of Interpretation Based on a Metaphor Theory. Biatostockie Archiwum Jezykowe no. 10: 47-67. https://jyx.jyu.fi/ dspace/handle/123456789/37115 last accessed on 18 Dec, 2015.

Granbom-Herranen, Liisa 2011. Proverb - a Literal Phrase And a Part of Everyday Speech. In: Antonio Pamies, Juan de Dios Luque Durán \& Patricia Fernández Martín (eds.) Paremiología y herencia cultural. Granada: Granada Lingvistica, 285-294. 
Granbom-Herranen, Liisa 2013a. Some Theoretical Aspects of Processes Behind the Meanings of Proverbs and Phrases. In: Joanna Szerszunowicz \& Bogusław Nowowiejski \& Katsumasa Yagi \& Takaaki Kanzaki (eds.) Intercontinental Dialogue on Phraseology 2: Research on Phraseology Across Continents 2. Białystok: The University of Bialystok Publishing House, 372-388.

Granbom-Herranen, Liisa 2013b. "Newspapers are the Schoolmasters of the Common People." Some Paremiological Notes of Proverbs in a Finnish Newspaper. In: Rui J.B. Soares \& Outi Lauhakangas (eds.) 6th Interdisciplinary Colloquium on Proverbs. Tavira: AIP-IAP 315-328.

Granbom-Herranen, Liisa 2013c. Stat, kyrka och familj: innehållet i allmogebarns uppfostran i Finland i början av 1900-talet [Upbringing of common people's children in early 20th-century Finland: church, society, family and the contents of targets] In: Barn (Norwegian Centre for Child Research), vol 31, 3/2013, 55-68.

Granbom-Herranen, Liisa 2014a. Beyond understanding: how proverbs violate Grice's cooperative principle. In: Anneli Baran \& Liisi Laineste \& Piret Voolaid (eds.) Scala Naturae. Festschrift in Honour of Arvo Krikmann. Tartu: ELM Scholarly Press, 107-120.

Granbom-Herranen, Liisa 2014b. “SMS-messages - context for traditional and modern proverbs". In: Vida Jesenšek \& Dmitrij Dobrovol'skij (eds.) Phraseologie und Kultur / Phraseology and Culture.ZORA $96,367-381$.

Granbom-Herranen, Liisa 2015. Some paremiological notes of proverbs in three Finnish newspapers. In: Rui J. B. Soares \& Outi Lauhakangas (eds.) 8th Interdisciplinary Colloquium on Proverbs. Tavira: International Association of Proverbs, 404-415.

Granbom-Herranen, Liisa 2016. Proverbial expressions and cultural context in archive materials. In: Joanna Szerszunowicz \& Bogusław Nowowiejski \& Katsumasa Yagi \& Takaaki Kanzak (eds.) Intercontinental Dialogue on Phraseology 3: Linguo-Cultural Research on Phraseology. Bialystok: University of Bialystok Publishing House, 503-518.

Granbom-Herranen, Liisa \& Babič, Saša \& Voolaid, Piret 2015. Proverbial Expressions in Newspapers. Comparative Study in Estonia, Finland and Slovenia. Traditiones: zbornik Instituta za slovensko narodopisje in Glasbenonarodopisnega inštituta ZRC SAZU = Acta Instituti ethnographiae et Instituti ethnomusicologiae Slovenorum, 44/3, 5-32.

Grice, H. P. 1975. Logic and Conversation. In: Peter Cole \& Jerry L. Morgan (eds.), Syntax and Semantics 3: Speech Acts. New York: Academic Press, 41-58.

Grzybek, Peter 1987. Foundations of Semiotic Proverb Study. Proverbium. An International Yearbook of Proverb Scholarship 4: 39-85.

Grönfors, Martti 1982. Kvalitatiiviset kenttätyömenetelmät. Porvoo: WSOY.

Headland, Thomas N. 1990. Introduction. A Dialogue Between Kenneth Pike and Marvin Harris on Emics and Etics. In: Thomas N. Headland \& Kenneth L. Pike \& Marvin Harris, Marvin (eds.) Emics and Etics. The Insider/Outsider Debate. Frontiers of Anthropology 7. Newbury Park: Sage, 13-27.

Honko, Lauri 1989. Folkloristic Theories of Genre. In: Anna-Leena Siikala (ed.) Studies in Oral Narrative. Studia Fennica 33. Helsinki: Suomalaisen Kirjallisuuden Seura, 13-28.

Jussila, Juhani \& Montonen, Kaisu \& Nurmi, Kari 1992. Systemaattinen analyysi kasvatustieteiden tutkimusmenetelmänä. In: Terttu Gröhn \& Juhani Jussila (eds.) Laadullisia lähestymistapoja koulutuksen tutkimuksessa. Helsinki: Yliopistopaino, 157-208.

Järv, Risto 1999. Is Providing Proverbs a Tough Job?: References to Proverbs in Newspaper Texts. Folklore 10: 77-107. http://folklore.ee/folklore/vol10/pdf/rjrv.pdf, last accessed on 15 March, 2015. 
Krikmann, Arvo 2005. Delfi - peldikusein voi aardelaegas [Comments at the Internet Portal Delfi - Toilet Wall or Treasure Box?]. www.folklore.ee/Haldjas10/ppts/KrikuDelfi.ppt, last accessed on 15 March, 2015.

Kuusi, Matti (ed.) 1990 [1953]. Vanhan kansan sananlaskuviisaus [The Wisdom in Proverbs of the Ancient Folk]. Helsinki: WSOY.

Lauhakangas, Outi 2013. Proverbs, Fragments and Modifications of Proverbs in the Most Widely Read Finnish Newspaper (The Newspaper Project). In: Rui J. B. Soares \& Outi Lauhakangas (eds.), 6th Colóquio Interdisciplinar sobre Proverbios. Tavira: IAP-AIP, 421-440.

Laukkanen, Kari \& Pekka Hakamies (eds.) 1997 (1978). Sananlaskut [Proverbs]. Helsinki: Suomalaisen Kirjallisuuden Seura.

Lüthi, Max. 1970. Das Sprichwort in der Zeitung. Proverbium 15: 495-497.

Mieder, Wolfgang 1971. Verwendungsmöglichkeiten und Funktionswerte des Sprichwortes in der Wochenzeitung (Untersuchung der Zeit für das Jahr 1971). Muttersprache, 83 (1973), 89-119.

Mieder, Wolfgang 1993. Proverbs Are Never Out of Season: Popular Wisdom in the Modern Age. Oxford: Oxford University Press.

Mieder, Wolfgang 2004. Proverbs. A Handbook. Westport, Connecticut \& London: Greenwood Press.

Mieder, Wolfgang 2008. "Proverbs Speak Louder Than Words": Folk Wisdom in Art, Culture, Folklore, History, Literature, and Mass Media. New York, Washington, D.C./Baltimore, Bern, Frankfurt am Main, Berlin, Brüssels, Vienna, Oxford: Peter Lang.

Mieder, Wolfgang 2014. Futuristic Paremiography and Paremiology. Folklore Fellows' Network, No 44, 13-17. http://www.folklorefellows.fi/wp-content/uploads/FFNetwork_44.pdf, last accessed on 15 August, 2016.

Nirvi, R. E. \& Lauri Hakulinen (eds.) 1953 (1948). Suomen kansan sananparsikirja [Book of Finnish Proverbs]. Porvoo: WSOY.

Norrick, Neal R. 1985. How Proverbs Mean. Semantic Studies in English Proverbs. New York: Mouton.

Piltz, Klaus Dieter 1989. Phraseologie in der (regionalen) Tageszeitung am Beispiel einer Ausgabe der Westdeutschen Allgemeinen Zeitung (=WAZ) vom Samstag / Montag, 30. Dez. 1989 / 1. Jan. 1990. In: Christine Palm (ed.) Europhras 90. Akten der internationalen Tagung zur germanistischen Phraseologieforschung. Uppsala: Acta Universitatis Upsaliensis, 1991, 181-209.

Putnam, Hilary 1975. Meaning of meaning. In: Keith Gunderson (ed.) Language, Mind and Knowledge. Minnesota Studies in the Philosophy of Science VII. Minneapolis: University of Minnesota Press.

Taylor, Archer 1981. The Wisdom of Many and the Wit of One. In: Wolfgang Mieder \& Alan Dundes (eds.) 1981. The Wisdom of many. Essays on the Proverb. New York \& London: Garland Publishing, 3-9.

Voolaid, Piret 2013. On Paremiological Findings in the Estonian Daily Newspaper Postimees (Newspaper Project). In: Rui J. B. Soares \& Outi Lauhakangas (eds.), 6th Interdisciplinary Colloquium on Proverbs. Tavira: IAP-AIP, 291-303.

Vygotski, Lev 1967. Thought and Language, Cambridge, MA: The MIT Press. 


\section{SMS SPOROČILA V FINSKEM ČASOPISU KONTEKST IZVEDB PREGOVOROV}

Avtorica se osredinja na finske pregovore kot del sodobnega pogovornega pisnega jezika v vsakdanji rabi in kontekstu. Clanek ponuja pogled na to, kaj se dogaja s pregovori v domačem jeziku v finskem vsakdanjiku. Večina tradicionalnih finskih pregovorov izvira iz agrarnega konteksta in še vedno uporablja ta jezik, čeprav gre danes za nove kontekste z novimi pomeni. Empirično gradivo za razpravo so pregovori v finskem časopisu, natančneje, pregovori v SMS sporočilih, objavljenih kot pisma uredniku časopisa.

Na eni strani avtorica $z$ analizo sodeluje v razpravi o rabi pregovorov $v$ različnih obdobjih in $v$ različnih kontekstih, pri čemer sta njen fokus tako kratkoživi izreki (moderni pregovori) kot izrazi za družbeno stabilnost in počasi spreminjajoče se strukture (tradicionalni pregovori, biblični citati). Na drugi strani pa razbira pregovore kot kratke predstave ali kot del predstave, pri čemer posebej analizira podobnosti pri uporabi pregovorov v ustni ali pisni obliki finskega jezika.

Dr. Liisa Granbom-Herranen, University of Jyvaskyla, Finland, liisa.granbom-herranen@jyu.fi 